\title{
PENCEGAHAN KEKERASAN TERHADAP PEREMPUAN DAN ANAK DALAM EKOLOGI KELUARGA
}

\author{
Ina Salmah Febriany \\ Universitas Attahirriyah Jakarta \\ inafebriany@gmail.com
}

\begin{abstract}
Abstrak: Fenomena kekerasan terhadap perempuan dan anak yang telah ada jauh sebelum agama Islam lahir adalah bentuk kekejaman yang semestinya kita hentikan. Praktik perbudakan zaman Jahiliyah, sebagai bukti adanya kekerasan terhadap perempuan dan anak kini muncul kembali dalam bentuk baru; trafficking perempuan dan anak, pelecehan seksual hingga kasus yang terjadi sepanjang April 2016 ini; perkosaan sekaligus pembunuhan sadis oleh belasan lelaki (sebagian dari mereka masih berstatus pelajar), terhadap anak di bawah umur (Yuyun, 14), kasus perkosaan terhadap bayi 2,5 tahun hingga meninggal dunia oleh paman temannya sendiri saat ia bermain tanpa pengawasan juga kasus Enno (19) yang diperkosa secara bergilir oleh ketiga teman lelakinya hingga meninggal dunia dalam kondisi mengenaskan; kemaluan korban ditusuk gagang cangkul hingga tembus ke paru-paru sedalam puluhan meter. Mattensich dan Hill mengungkapkan bahwa fungsi keluarga terdiri atas pemeliharaan fisik sosialisasi dan pendidikan, akuisisi anggota keluarga baru melalui prokreasi atau adopsi, kontrol perilaku sosial dan seksual, pemeliharaan moral keluarga dan pendewasaan anggota keluarga melalui pembentukan pasangan seksual, dan melepaskan anggota keluarga dewasa. Sebab keluarga menjadi salah satu kontrol perilaku sosial dan seksual, maka sudah saatnya kita 'kembali' dan memulai pendidikan dari keluarga untuk pertahanan dan penguatan sosial masyarakat. Hal ini penting mengingat keluarga sebagai unit sosial-ekonomi terkecil dalam masyarakat yang merupakan landasan dasar dari semua institusi.
\end{abstract}

Kata Kunci: kekerasan seksual, ekologi keluarga, perempuan dan anak

\section{Mengkaji Ulang Kekerasan Terhadap Perempuan}

Sebagai agama yang bertujuan menjadi rahmat bagi seluruh alam, Islam menganjurkan pemeliharaan dua hubungan yakni secara vertikal maupun horisontal. Secara vertikal ialah hubungan manusia kepada Allah SWT melalui serangkaian ibadah. Ibadah ini diharapkan mampu menciptakan hubungan yang baik antara hamba dengan Allah SWT (hablu min Allah).

Tak cukup hanya pemeliharaan hubungan baik dengan Allah, secara horisontal, manusia juga dianjurkan untuk berinteraksi dengan sesama sebagai bukti bahwa manusia ialah makhluk sosial yang saling membutuhkan. Sifat saling membutuhkan inilah diharapkan mampu melahirkan hubungan yang harmonis antara laki-laki dan perempuan (habl min an-nâs).

Dari interaksi sosial antara lelaki dan perempuan inilah, keduanya dianjurkan bekerja sama, saling menolong, serta berlomba dalam kebaikan karena Allah SWT telah menjanjikan pahala yang sama baik lelaki dan perempuan yang beriman ketika mereka melakukan kebaikan. Selain ganjaran pahala, keduanya juga mendapatkan peranan, hak dan kewajiban.

Keseimbangan peranan, hak dan kewajiban tanpa mengabaikan jenis kelamin yang telah termaktub melalui firman Allah SWT, pada 
kenyataannya belum berjalan dengan nilai-nilai yang dikehendaki Al-Qur'an yaitu keadilan antara kedua ciptaan-Nya-lelaki dan perempuan-tanpa harus ada yang menindas atau merasa superior antara satu dengan lainnya.

Jika kita melihat dari sejarah lahirnya agama Islam, agama ini hadir di tengah-tengah masyarakat Arab yang sarat dengan praktik dan budaya diskriminatif dan memarjinalkan perempuan. Tradisi masyarakat saat itu, perempuan dipandang sebagai manusia kelas dua (second sex), manusia yang bermartabat rendah, tidak berharga juga tidak memiliki hak atas hidup mereka. Karena itu, hak perempuan sepenuhnya berada di tangan laki-laki (Subhan, 2004).

Budaya diskriminatif itu melahirkan praktik kekerasan terhadap perempuan yang tergambar pada masyarakat Arab. Mereka malu jika dianugerahi anak perempuan. Sebab, menurut pandangan orang Arab Jahiliyah, mempunyai anak perempuan adalah suatu aib. Anggapan lain, perempuan dinilai lemah karena tidak mempunyai kekuatan untuk turut serta berperang-yang memang perang adalah modal kekuatan bangsa Arab kala itu.

Kisah dikuburnya bayi perempuan pada tradisi Arab Jahiliyah tertera dalam QS AnNahl/16: 58-59: "Dan apabila seseorang dari mereka diberi kabar kelahiran anak perempuan, hitamlah (merah padam) mukanya, dan dia sangat marah. Dia menyembunyikan dirinya dari orang banyak, disebabkan buruknya berita yang disampaikan kepadanya. Apakah dia akan memeliharanya dengan menanggung kehinaan ataukah akan menguburkannya ke dalam tanah (hidup-hidup)? ketahuilah, Alangkah buruknya apa yang mereka tetapkan itu." (An-Nahl/16: 5859).

Pendeskripsian Al-Qur'an mengenai masyarakat Arab Jahiliyah yang malu jika dikaruniai perempuan seperti tersurat dalam ayat di atas menyebabkan lahirnya anggapan bahwa perempuan ada di dalam kontrol laki-laki, dimana saat itu perempuan sangat tidak memiliki hak untuk hidup.

Ayat inilah sebagai salah satu isyarat betapa masyarakat Arab Jahiliyah menganggap bahwa memiliki anak perempuan hanyalah musibah yang membuat mereka enggan memelihara amanat itu. Melalui ayat ini pulalah kekerasan secara psikis era Arab Jahiliyah tergambar secara konkrit.

Kekerasan terhadap perempuan adalah setiap perbuatan berdasarkan pembedaan kelamin yang berakibat atau mungkin berakibat kesengsaraan dan penderitaan perempuan secara fisik, seksual atau psikologis, termasuk ancaman tindakan tertentu, pemaksaan atau perampasan kemerdekaan secara sewenang-wenang baik yang terjadi di depan umum maupun dalam kehidupan pribadi (Menteri Negara Pemberdayaan Perempuan, 2010).

Mencermati definisi di atas pula, maka kekerasan terhadap perempuan dikategorikan sebagai perbuatan tak bermoral karena melibatkan kesengsaraan si korban baik secara psikis, fisik, seksual. Ketiga hal tersebut menyebabkan perempuan yang dalam hal ini sebagai korban, sering mengalami trauma berkepanjangan. Terlebih dahulu, pada zaman pra-Arab, dimana perempuan dianggap makhluk tak bernilai.

Selain pada zaman Arab Jahiliyah, kondisi mengenaskan yang terjadi pada wanita telah ada sejak zaman Yunani kuno dimana perempuan hanya dipandang sebagai fasilitas kenikmatan seksual. Pada peradaban Romawi, perempuan dapat diperjualbelikan. Sedangkan pada peradaban India menganggap bahwa perempuan adalah makhluk najis karena mereka tidak berhak hidup jika suaminya meninggal dunia. (Muhith, 2010).

Dari keempat peradaban tentang wanita tersebut di atas, perspektif teologi pun turut 


\section{8-33 | HARKAT: Media Komunikasi Islam Tentang Gender dan Anak, 12 (1), 2016}

memberikan sumbangsihnya dalam memandang perempuan. Sekiranya terdapat empat faktor yang berpotensi menjadi sebab penting dalam mempengaruhi pembentukan anggapan stereotip terhadap perempuan. Keempat hal ini timbul dari penafsiran keliru atas teks suci.

Pertama, anggapan bahwa perempuan tercipta sebagai pelengkap Adam. Kedua, gambaran surga telah melahirkan pelbagai mitos yang merendahkan perempuan. Ketiga, anggapan perempuan tercipta dari tulang rusuk laki-laki menjadikan posisi wanita lebih rendah dari lakilaki. Keempat, anggapan bahwa godaan perempuanlah yang menyebabkan Adam dan Hawa terusir dari surga. (Muda, 2007).

Keempat pandangan stereotip inilah pada akhirnya melahirkan berbagai kekeliruan dalam memperlakukan perempuan-yang semestinya, perempuan adalah makhluk yang setara dengan lelaki, di samping pasti memiliki banyak perbedaan yang telah dianugerahkan-Nya. Beberapa anggapan kurang baik terhadap perempuan sebagai buah interpretasi manusia itu sendiri, pada akhirnya menempatkan perempuan dalam posisi rentan kekerasan.

Bentuk kekerasan terhadap perempuan secara umum dapat dikelompokkan ke dalam dua kategori yaitu kekerasan dalam ranah domestik (rumah tangga) dan kekerasan di ranah publik (di luar rumah tangga). (Subhan, 2008). Dalam lingkup domestik, kekerasan dalam rumah tangga sering diistilahkan dengan KDRT. Kekerasan dalam rumah tangga dapat berupa penganiayaan fisik misalnya pukulan, tamparan, atau tendangan, penganiayaan psikis atau emosional misalnya penghinaan, pelecehan, cemoohan dan ancaman, melukai hati dan perasaan, merendahkan harga diri, mengancam akan menceraikan dan memisahkannya dengan anak-anak. Dan kekerasan ekonomi artinya tidak memberikan nafkah, menguasai hasil kerja isteri, memaksa isteri bekerja untuk suami. Juga ada kekerasan seksual yaitu bisa berupa tidak memenuhi kebutuhan seksual isteri, memaksakan isteri menggugurkan kandungan, memaksakan kehendak kepada isteri, dan lain sebagainya. (Subhan, 2008).

Kekerasan terhadap perempuan tidak terlepas dari faktor budaya yang melegitimasi tindakan kekerasan tersebut. Budaya patriarki yang dominan telah menimbulkan penilaian bahwa kekerasan terhadap perempuan bukan merupakan sebuah kekerasan, tapi adalah sesuatu yang wajar diterima perempuan (Subhan, 2008).

Sementara realitas kekerasan tersebut, dalam konteks Indonesia, bukan hanya dalam ranah tradisi, adat istiadat, kesenian, ekonomi, ilmu pengetahuan, namun juga pada 'atas nama' agama (tafsir keagamaan). (Zaitunah Subhan, 2005)Akhirnya, persoalan kekerasan terhadap perempuan masuk juga ke ranah teks suci AlQur'an yang dijadikan sumber legitimasi mengenai hubungan antara lelaki dan perempuan.

Namun problemnya, ketika masuk ke wilayah teks, ternyata pemahaman dan kesimpulan yang muncul tidak selalu satu, melainkan mendua atau bahkan masih membuka peluang untuk interpretasi lain (Hidayat, 2008). Karena banyaknya interpretasi itulah memungkinkan terjadinya kekeliruan dalam penafsiran yang perlu dikaji ulang agar tidak terjadi praktik diskriminatif antara lelaki dan perempuan dalam menafsirkan ayat- ayat Tuhan.

Dapat dianalisis mengapa perspektif diskriminatif atau subordinatif terjadi dalam wacana pemikiran keagamaan. Misalnya pertama, karena kekeliruan dalam menginterpretasikan bunyi teks secara harfiah. Kedua, karena cara atau metode penafsiran secara parsial atau tidak utuh, sepotong, atau sebagian. Terakhir, karena seringkali didasari dan dikuatkan oleh hadits-hadits lemah (dhaîf) atau bahkan hadits palsu (mau'dhu) atau hadits israiliyyat. Tiga kemungkinan ini pada akhirnya terakumulasi dalam interpretasi dan sering 
kurang memperhatikan sosio kultural dimana, pada siapa, bagaimana dan kapan firman itu diturunkan (Subhan, 2008).

Sejatinya, Allah menciptakan perempuan dan lelaki ialah untuk saling melengkapi. Dengan kata lain, tidak memberikan perempuan hakhaknya sebagai mitra yang sejajar dengan lelaki dan meremehkannya tidak jarang menggunakan dalih keagamaan serta memberi interpretasi terhadap teks - interpertasi yang lahir dari pandangan lama ketika perempuan masih dilecehkan di masa lalu (Shihab, 2010).

Lebih lanjut, masih menurut Muhammad Quraish Shihab, interpretasi itu lahir dari bias lama dimana dalam literatur agama ditemukan sekian banyak riwayat yang dinilai lahir dari sisasisa pandangan lama terhadap perempuan (Shihab, 2010). Artinya interpretasi teks yang hadir ke tengah-tengah masyarakat masih dimungkinkan bahwa Nabi dan para sahabat tidak 'bermaksud' seperti apa yang mereka pahami. Kekeliruan dalam memahami hadits apalagi Al-Qur'an, sangat mungkin terjadi. Oleh karenanya, diperlukan ketelitian, penguasaan ilmu serta pemahaman yang objektif dan berkeadilan universal. Kekeliruan itulah yang akhirnya menyebabkan perempuan ada dalam posisi rentan dan dalam anggapan bahwa perempuan ada di bawah kekuasaaan lelaki yang pada akhirnya mengesampingkan misi yang sebenarnya dari Al-Qur'an, sebagai pedoman hidup umat islam yang menyuarakan keadilan.

Keadilan menurut hukum negara dan agama umumnya adalah keadilan yang didasarkan pada teks, yaitu teks perundangan dan teks agama. Teks perundangan ditafsirkan oleh aparat hukum, teks agama ditafsirkan oleh tokoh agama. Ketika perempuan tidak menjadi bagian dari penafsir kedua teks tersebut, maka keadilan versi hukum negara dan agama tersebut pun cenderung abai terhadap kondisi spesifik perempuan, khususnya perempuan korban kekerasan (Uzm, 2008).
Sebab makin maraknya kasus kekerasan seksual dewasa ini, maka pendidikan dalam keluarga dinilai sangat dan teramat penting guna membentengi diri perempuan dan anak dalam menghadapi pelbagai kasus kekerasan. Pendidikan itu diantaranya adalah pendidikan spiritual (penanaman aqidah), pendidikan emosional (sugesti positif dari orangtua untuk berani melawan kejahatan sekitar), pendidikan fisik (mengajarkan teknik seni beladiri) dan pendidikan seksual (memberikan pemahaman bagian tubuh yang tidak boleh dijamah orang lain selain orangtuanya).

\section{Diskursus Tentang Keluarga dan Ekologi Keluarga}

Keluarga merupakan salah satu insitusi terdekat dari anak yang memiliki pengaruh signifikan dalam perkembangannya sebagai manusia. Dalam keluarga terdapat fungsi dan nilai-nilai tertentu yang dianut, yang merupakan bagian dari konstruksi sosial yang berlaku di wilayah atau komunitas tertentu (Hastadewi, 2000).

Sebagai sebuah institusi terdekat bagi anak, keluarga mempunyai beberapa fungsi, yakni: fungsi sebagai tempat pemenuhan kebutuhan jasmani dasar (memeroleh makanan, minuman, gizi, pakaian), sebagai tempat pemenuhan kebutuhan psikologis (afeksi, kasih sayang, perhatian), sebagai tempat istirahat, dan sebagai tempat pengenalan dan penanaman nilai-nilai tertentu (Hastadewi, 2000).

Begitu dalamnya makna keluarga yang diurai oleh Hastadewi di atas. Keseluruhan komponen penting yang berhak anak peroleh ialah pertama dari keluarga; terutama Ibu dan ayahnya. Tiga fungsi di atas yaitu kebutuhan jasmani, psikologis dan tempat penanaman nilai harus dilakukan secara kontinyu dan berimbang. Kualitas waktu tak akan pernah tercipta tanpa 


\section{0-33 | HARKAT: Media Komunikasi Islam Tentang Gender dan Anak, 12 (1), 2016}

ketiadaan kuantitas. Hal ini penting terlebih di enam tahun pertama usia anak.

Karenanya, dalam al-Quran surah an-Nisa ayat 9, Allah Swt menekankan agar para orangtua benar-benar memerhatikan kondisi anaknya dan tidak dianjurkan untuk meninggal anak (dzurriyyah) dalam kondisi lemah (dhi'afan). Baik lemah secara iman dan juga lemah secara ketiga fungsi yang telah disebutkan di atas. "Dan hendaklah orang-orang takut kepada Allah, bila seandainya mereka meninggalkan anak-anaknya, yang dalam keadaan lemah, yang mereka khawatirkan terhadap (kesejahteraan) mereka. Oleh sebab itu, hendaklah mereka bertakwa kepada Allah dan mengucapkan perkataan yang benar"

Penekanan dan anjuran yang Allah ungkap di awal ayat, memberi isyarat bahwa para orang tua sebaiknya betul-betul memerhatikan kondisi anak dan menjaga pertahanan keluarga agar senantiasa aman dan selalu memberikan perhatian serta teladan yang baik. Jika dari dalam keluarga sebagai institusi terkecil anak diajarkan hal-hal baik, maka ia pun diharapkan mampu berinteraksi dengan baik dalam lingkup yang lebih luas. Oleh karena itu, ekologi sebagai ilmu yang membahas tentang keterkaitan individu dengan makhluk lainnya dinilai relevan dalam tulisan ini.

Istilah ekologi menyiratkan tentang keterkaitan salah satu makhluk hidup dengan makhluk lainnya. Secara etimologi, kata ekologi berasal dari bahasa Yunani "oicos" (rumah tangga) dan "logos" (ilmu), yang diperkenalkan pertama kali dalam bidang biologi oleh seorang biolog Jerman bernama Ernts Hackel. (Koesnadi, 1994: 1-2). Dalam perkembangan berikutnya, ilmu ekologi dikenal sebagai disiplin ilmu yang membahas tentang hubungan antara satu organisme dengan lainnya atau antara organisme tersebut dengan lingkungannya. Lebih lanjut, ekologi secara harfiah juga berarti ilmu tentang makhluk hidup dalam rumahnya atau ilmu tentang rumah tangga makhluk hidup (Ricklefs, 1973).

Pengertian ekologi yang lebih komprehensif juga diungkapkan oleh Lipietz dengan menyatakan adanya tiga bentuk relasi dalam ekologi yaitu: relasi secara individu atau satu jenis kelompok, aktivitas yang terorganisasi, dan hasil dari aktivitas yang mereka kerjakan, yang pada gilirannya, keseluruhan komponen itu akan saling memengaruhi keadaan pada individual lainnya. (Lipietz, 1999).

Namun secara umum, ekologi juga diartikan sebagai studi tentang organisme di dalam lingkungan alamiahnya. Oleh sebab itu, ruang lingkup studi ekologi sangat luas mencakup interaksi antara organisme, populasi, komunitas, ekosistem, eksosfer, atmosfer, hidrosfer dan litosfer (Giplin, 1980).

Berdasarkan beberapa definisi di atas, secara umum dapat kita simpulkan bahwa ekologi adalah ilmu yang membahas tentang keterikatan satu makhluk hidup dengan lainnya. Oleh karenanya, ekologi keluarga dapat kita uraikan sebagai keterikatan antara satu anggota keluarga dengan lainnya juga antar keluarga dengan lingkup yang lebih luas. Definisi ini dapat kita deskripsikan seperti gambar di bawah ini:

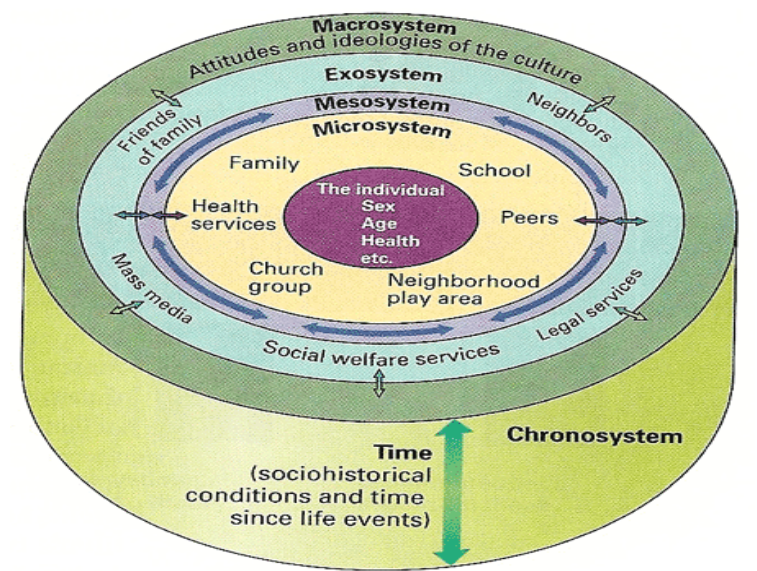

Gambar di atas ialah buah pemikiran (teori) ekologi yang dikembangkan oleh Urie Bronfenbrenner (1917) yang fokus utamanya adalah pada konteks sosial di mana anak tinggal 
dan orang-orang yang memengaruhi perkembangan anak. Lima sistem lingkungan teori ekologi Bronfenbrenner terdiri dari lima sistem lingkungan yang merentang dari interaksi interpersonal sampai ke pengaruh kultur yang lebih luas. (Santrock, 2010). Sebuah mikrosistem adalah setting dimana individu menghabiskan banyak waktu. Beberapa konteks dalam sistem ini antara lain adalah keluarga, teman sebaya, sekolah, dan tetangga dan lingkup yang lebih luas lagi.

Dalam mikrosistem ini, individu berinteraksi langsung dengan orang tua, guru, teman seusia, dan orang lain. Menurut Bronfenbrenner, murid bukan penerima pengalaman secara pasif di dalam setting ini, tetapi murid adalah orang yang berinteraksi secara timbal balik dengan orang lain dan membantu mengkonstruksi setting tersebut. Karenanya, di usia sekolah, jika kedekatan emosional dan frekuensi waktu yang diterima anak justeru lebih banyak dari guru dibanding orangtuanya, maka anak lebih menyerap dan mudah mendengar apa yang dikatakan gurunya.

Setelah mikrosistem, istilah lain yang dikenal dalam terori ini adalah mesosistem yang merupakan kaitan antar-mikrosistem. Contoh adalah hubungan antara pengalaman dalam keluarga dengan pengalaman di sekolah, dan antara keluarga dan teman sebaya. Misalnya, salah satu mesosistem penting adalah hubungan antara sekolah dan keluarga. Dalam sebuah studi terhadap seribu anak kelas delapan (atau setingkat kelas 3 SMP ke awal SMA (Epstein, 1983).

Murid yang diberi kesempatan lebih banyak untuk berkomunikasi dan mengambil keputusan, entah itu di rumah atau di kelas, menunjukkan inisiatif dan nilai akademik yang lebih baik. Lain halnya jika anak yang kurang mampu berkomunikasi atau justeru interaksi sosial yang terlalu dikekang atau dibatasi orangtuanya, cenderung pendiam dan introvert (tertutup) terhadap orang di sekelilingnya.

Selain mikrosistem dan mesosistem yang saling berkaitan, eksosistem (exosystem) terjadi ketika pengalaman di setting lain (dimana murid tidak berperan aktif) memengaruhi pengalaman murid dan guru dalam konteks mereka sendiri. Misalnya, ambil contoh dewan sekolah dan dewan pengawas taman di dalam suatu komunitas. Mereka memegang peran kuat dalam menentukan kualitas sekolah, taman, fasilitas rekreasi, dan perpustakaan. Keputusan mereka bisa membantu atau menghambat perkembangan anak. Keputusan satu pihak yang terkadang membuat pasif pihak lain, dalm hal ini sekolah dan pelajar, tak jarang membuat anak terpaksa melakukan apa yang diperintahkan sekolah. Penambahan jam belajar tanpa boleh negosiasi waktu lagi, misalnya.

Selain tiga istilah di atas, dikenal pula makrosistem adalah kultur yang lebih luas. Kultur adalah istilah luas yang mencakup peran etnis dan faktor sosioekonomi dalam perkembangan anak. Kultur adalah konteks terluas dimana murid dan guru tinggal, termasuk nilai dan adat istiadat masyarakat. Misalnya, beberapa kultur (seperti di negara Islam semacam Mesir atau Iran), menekankan pada peran gender tradisonal. Kultur lain (seperti di AS) menerima peran gender yang lebih bervariasi. Di kebanyakan negara Islam, sistem pendidikannya mempromosikan dominasi pria.

Selanjutnya, kronosistem adalah kondisi sosiohistoris dari perkembangan anak. Bronferbrenner memberi perhatian lebih tentang kronosistem sebagai sistem lingkungan yang penting. Dia memerhatikan dua problem penting: (1) banyaknya anak di Amerika yang hidup dalam kemiskinan, terutama dalam keluarga single-parent; dan (2) penurunan nilainilai (Bronferbrenner dkk., 1996). 


\section{Mengkaji Ulang Penyebab Kasus Perkosaan Terhadap Yuyun}

Salah satu aspek dari status sosiekonomi murid adalah faktor perkembangan dalam kemiskinan. Kemiskinan dapat memengaruhi perkembangan anak dan merusak kemampuan mereka untuk belajar, meskipun beberapa anak di lingkungan yang miskin sangat ulet. Kemiskinan juga terkadang membuat seorang anak harus berjuang ekstra keras dalam belajar, meski tanpa dampingan orangtua; disebabkan orangtua mereka harus bekerja agar bisa membiayai anak-anaknya. Sebagai contoh dari kasus Yuyun (14), bocah yang masih duduk di bangku SMP yang harus wafat dalam kondisi mengenaskan setelah disetubuhi belasan remaja desa yang pengangguran (beberapa di antaranya masih berstatus pelajar). Setelah ditelusuri lebih lanjut dari berbagai macam pemberitaan media, ditemukan bahwa lokasi tempat Yuyun tinggal adalah daerah miskin, baik miskin secara kultural, natural dan sttruktural.

Miskin secara kultural adalah rendahnya kesadaran masyarakat untuk bekerja juga masih sedikitnya lapangan pekerjaan yang tersedia. Hal ini diperparah karena kondisi Padang Ulak Tanding, Bengkulu, masuk ke dalam kategori daerah yang rendah ketersediaan Sumber Daya Alam. Dengan demikian, desa tempat Yuyun tinggal juga miskin secara natural. Terakhir, miskin secara struktural, disebabkan karena buruknya sistem pemerintahan, korupsi yang dilakukan para pejabat, hingga membuat sengsara rakyat dan mereka pun hidup melarat.

Definisi lain perihal kemiskinan diungkap oleh Mardimin, yaitu:

1. Secara kualitatif, definisi kemiskinan adalah suatu kondisi yang didalamnya hidup manusia tidak layak sebagai manusia, dan

2. Secara kuantitatif, kemiskinan adalah suatu keadaan dimana hidup manusia serba kekurangan, atau dengan bahasa yang tidak lazim "tidak berharta benda" (Mardimin, 1996).

Definisi kemiskinan yang telah dipaparkan di atas memberikan kita gambaran bahwa kemiskinan dalam pengertian yang lebih luas akan berakibat fatal terhadap perkembangan dan kehidupan anak. Dalam hal ini, selain teori keluarga, Teori Strategi Kelangsungan Rumah Tangga (Household Survival Strategy). Menurut Teori ini, dalam masyarakat pedesaan yang mengalami transisi dan golongan miskin di kota, mereka akan memanfaatkan sumber-sumber yang tersedia bila kondisi ekonomi mengalami perubahan atau memburuk. Salah satu upaya yang seringkali dilakukan untuk beradaptasi dengan perubahan adalah memanfaatkan tenaga kerja keluarga.

Kalau tenaga kerja wanita terutama Ibu Rumah Tangga belum dapat memecahkan masalah yang dihadapi biasanya anak-anak yang belum dewasa pun diikutsertakan dalam menopang kegiatan ekonomi keluarga (Bagong, 2000).

Senada dengan kasus yang menimpa Yuyun, siswi Kelas VIII SMP Negeri 5 Satu Atap, Kecamatan Padang Ulak Tanding, Kabupaten Rejang Lebong, Bengkulu, yang diperkosa hingga meninggal dunia oleh 14 pemuda mabuk. Kasus ini terlambat diberitakan oleh media nasional karena letak desa Yuyun yang terpencil dan baru terkuak setelah salah seorang guru Yuyun berani melaporkan kasus keji ini ke polisi meski ia sempat diteror oleh keluarga korban. (Liputan 6. Com: Kamis, 5 Mei 2016, 14.50 Wib).

Perempuan yang masih duduk di bangku SMP ini tewas setelah dipukul di bagian kepalanya. Nama Yuyun kini dikenal publik sebagai simbol kekerasan seksual terhadap perempuan. Yuyun hilang pada Sabtu, 2 April, dan baru ditemukan tiga hari kemudian, pada Senin, 4 April 2016. 
Berdasarkan rekonstruksi yang dilakukan pada 14 pelaku di Markas Polres Rejang Lebong, Bengkulu, pada 19 April selama 3 jam, kebanyakan umur pelaku di bawah 20 tahun. Yuyun, yang pada Sabtu sore itu baru pulang sekolah dan masih mengenakan seragam SMP, melintas di area para pelaku yang sedang bermabuk-mabukan.

Melihat anak perempuan berusia 14 tahun itu melintas di depan mereka, para pelaku langsung memerkosa dan membunuh serta membuang jasadnya ke jurang sedalam lima meter. Yuyun memang terbiasa pulang sendiri tanpa teman apalagi orangtuanya. Jarak antara sekolah ke rumah pun cukup jauh dan harus melewati perkebunan karet yang sehari-harinya sangat jarang orang melintas.

Kasus Yuyun hendaknya menjadi pelajaran kita bersama, terlebih keluarga dan para orang tua agar lebih menguatkan peranan dan perlindungan kepada anak. Anjuran al-Quran agar tidak meninggalkan anak dalam kondisi lemah (dalam hal kasus Yuyun lemah secara ekonomi), memberikan sebuah hikmah bahwa orang tua perlu berbagi tugas. Jika ayah keluar bekerja penuh waktu, maka Ibu sebaiknya memiliki keahlian khusus agar tetap membantu perekonomian keluarga tanpa harus keluar terlalu lama dari rumah. Hal ini sejalan dengan teori ekologi keluarga; untuk menguatkan interaksi antara orangtua dan anak di rumah, guna menghindari hal-hal buruk yang mungkin terjadi di luar.

\section{Daftar Pustaka}

Bagong, Suyanto. 2000. Pekerja Anak, Masalah, Kebjakan, dan Upaya Penanganannya. Surabaya: Penerbit Lutfansah Mediatama.

E Ricklefs, Robert. 1973. Ecology. New York: Chiron Press
Giplin, Alan (ed). 1980. Dictionary of Environment Terms. Australia: University of Queesland Press

Harjasoemantri, Koesnadi. 1994. Hukum Tata Lingkungan. Yogyakarta: Gadjah Mada University Press

Hastadewi, Yuli. 2000 . Keluarga. Medan: Penerbit Yayasan PKPA

Komaruddin Hidayat. 2008. dalam Menggagas Fiqh Pemberdayaan Perempuan

Lipietz, Alain. 1999. Cultural Geography, Political Economy and Ecology, European Planning Studies.

Mardimin, Yohanes. 1996. Kritis Proses Pembangunan di Indonesia. Yogyakarta: Penerbit Kanisius

Menteri Negara Pemberdayaan Perempuan "Pengetahuan Praktis tentang Perlindungan terhadap Perempuan Korban Kekerasan”Jakarta: t.p

Muda, Fauzi Ahmad. 2007. Perempuan Hitam Putih: Pertarungan Kodrat Hidup vs Tafsir Kebahagiaan. Jakarta: Prestasi Pustaka

Muhith, Nur Faizin. 2010. Perempuan Ditindas atau Dimuliakan? Menguak RahasiaRahasia Wanita Dalam Al-Qur'an. Jakarta: Afra

Quraish Shihab, Muhammad. 2010. Perempuan. Jakarta: Lentera Hati

Santrock, John W. Psikologi Pendidikan. Universty of Texas-Dallas

Subhan, Zaitunah. 2004. Kekerasan Terhadap Perempuan, Yogyakarta: LKiS

Subhan, Zaitunah. 2008. Menggagas Fiqh Pemberdayaan Perempuan. Jakarta: elKAHFI

http://regional.liputan6.com/read/2498355/soso k-yuyun-korban-tewas-diperkosa-14abg-di-mata-sang-guru 